\title{
O primado da pedagogia da comunicação afetiva como via para o desenvolvimento da Mediação de Conflitos
}

Orientador: Prof. Dr. Abimar Oliveira de Moraes

abimar@puc-rio.br

Pesquisadora: Marisa Targiano S. de Carvalho

targiano@ig.com.br

Projeto de Pesquisa: Questões atuais de Teologia Pastoral

Fonte: $\mathrm{CNPq}$

Nessa pesquisa de fundamentação bíblica foi feita uma investigação sobre o modelo comunicacional predominante nas Escrituras Sagradas do Novo Testamento. Tomando como ponto de partida o reconhecimento de que o conflito é proveniente das dificuldades que temos de concretizar uma experiência relacional interpessoal e comunitária com senso de alteridade, objetivava identificar nos relatos bíblicos fundamentação antropológicoteológica para o discernimento teológico-pastoral dos procedimentos técnicos da mediação de conflitos. Servindo, assim, de fundamentação: na elaboração de ferramentas com o objetivo de proporcionar uma autêntica capacitação dos agentes de pastoral a trabalharem com as vítimas de violência dentro e fora do ambiente eclesial. 